\title{
Interest Rate Policy and the Growth of the Nigerian Economy (1990-2016)
}

\section{Edim Ndifon Obim ${ }^{\circledR}$ \\ John Ime John ${ }^{2}$ Akaninyene Billy Orok ${ }^{3}$}

${ }^{1,2,3}$ Department of Banking and Finance, Faculty of Management Sciences, University of Calabar, PMB 1115, Calabar, Nigeria

Email:Bimbim2016@unical.edu.ng.Tel:+2348037058721

${ }^{2}$ Email: Johnjohnjnr106@gmail.com Tel: +2348105723117

sEmail:akanorok@gmail.com Tel:+2348058036288

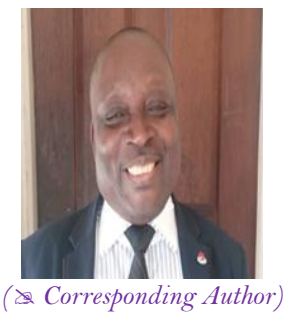

(T) Check for updates

\begin{abstract}
This study focused on the effect of interest rate policy on the growth of the Nigerian economy. It sought to assess the significance of interest rate, and to suggest measures that could enhance economic growth in Nigeria. To achieve the objective of the research, some macroeconomic indicators in the Nigerian economy, using an ex-post facto research design were applied. The data were analyzed using the Ordinary Least Square (OLS) method. From the examination, it was uncovered that there was a huge connection between financing cost and GDP in Nigeria. It was additionally found that there was a huge connection between rate for currency exchange and total national output in Nigeria. Inflation was likewise found to significantly affect total national output in Nigeria. In light of these discoveries, it is suggested that the Central Bank of Nigeria (CBN) ought to structure policy framework on the rate of interest that will dependably support and encourage culture of savings in the real sector. This can be accomplished by expanding the rate accruing to savings from foreign and local investors. Additionally, aggregate economic output should be seen as the bane of government policy thrust, through bringing down of rate charged to lending and expanding rate to savings, as this improves financial development.
\end{abstract}

Keywords: Financial intermediation, Deregulation, Loanable funds, Dishoarding.

\section{Introduction}

Money as a store of value and medium of exchange creates different types of claims. Essentially, those who lend money, expect to be compensated for handing over their liquidity for a stated period of time to users of money. This compensation constitutes interest rates, which is often expressed as a rate per cent per annum (Nzotta, 2004). Thus, interest represents payments made by an individual, a firm or organization for money used or borrowed.

It also constitutes the price for a loan or a measure of the percentage rate at which the current value of a debt grows over time, to equal the future payments. However, managing risk is an important function for business organizations dealing with money, which includes banks and non-bank institutions, thus, connoting the need for interest rate.

Nkemakolam (2017) explained the importance of interest rate as being dependent on its balancing influence on demand and supply in the monetary sector of an economy.

Colander (2001) confirmed that the diverting of funds into money related resources, and the ability of people to acquire monetary liabilities are unequivocally impacted by interest rate on those resources and liabilities. The part played by interest rate in formative and development of an economy is conceivable, in view of the interdependence between the real sector and financial sector of the economy (Orok et al., 2018).

Consequently, through this relationship, the impact of interest rate on the financial sector is disseminated to the real sector. This is evident, as lending rates charged by institutional lenders have a negative relationship with the aggregate level of investment in the Nigerian economy (Ojima and Fabian, 2015). Here, debt is a contractual obligation to repay specified amounts of money in future. Hence, interest rates could be said to be the price for money, paid by those who purchase money. Thus, the higher the lending rate charged by institutional lenders, the lower the aggregate level of investment in Nigeria.

However, on the other, when the rate of savings is high, it basically construe higher availability of funds to lend, as increase in the level of savings in the economy will lower the lending rate, through the market forces of demand and supply. Hence, increase in the propensity to save, leads to a decrease in the desire to invest, thus, making savings and investment to be inversely related.

Essentially, there is always at any one time, a variety of interest rates for different kinds of funds, depending on the purposes for which the money is sought, the maturity and the conditions on which it is offered. Here, we could distinguish between short and long term interest rates (Mankiw and Summers, 1984). Thus, interest rates vary with the term of the loan (short term rates versus long term rates), with the credit worthiness of the borrower (default - free rates versus risky rates). 
In the perspective of the traditional financial analysts, dimension of investment funds is dictated by rate of interest on savings (Olusoji, 2003).

According to this view, increment in interest rate paid to depositors result in high level of savings, and thus, a positive relationship ensue. Be that as it may, this view has supported regulatory authorizes in Nigeria to adopt the approach of economic reforms interest rate as opposed to determined interest rate.

The connection between investment and savings is no less vital as the total level of savings in an economy, assumes a key role in the level of investment in the economy. This forms the basis of monetary authorities using fiscal approaches in attempt to influence dimension of consolidated investment funds and the accessibility of loanable funds (Nkemakolam, 2017).

Again, the monetary policy framework, however, seeks to link the interest rate structure together essentially through the minimum rediscount rate.

Generally, changes in interest rates influence savings and investment in the Nigerian economy. Usually, a consumer holds cash balances to assist in making transactions in the future, up to a point where the marginal utility arising from holding an extra Naira balance, equate the marginal utility derived from spending the Naira balance on goods and services. Thus, as the real value of the consumers' increase, they may elect to switch into alternative uses of cash including the purchase of other goods.

It can be deduced that rates of interest standout amongst the most fundamental aspect of monetary framework that impact borrowing cost, and loan is a necessary means of financing production and businesses that translates to economic development.

The economic significance of the rate of interest in different nations of the world, Nigeria inclusive, is to guarantee adequate savings drive and mobilization for the economy (Orok et al., 2018).

It influences the returns that investors realize on their reserve funds. In the event that the enthusiasm on investment funds is empowering; people would be urged to spare more money not meant for consumption for investment, and this may allow for accessibility of loanable assets in the bank, and subsequently, improving development in the economy (Emori et al., 2017).

It is an imperative segment of the aggregate returns of numerous ventures, as interest rate give knowledge into future financial markets and monetary framework, in view of the dominance role interest play in the Nigerian economy (Powell, 2015).

Be that as it may, the Nigerian economy has at various occasions seen colossal loan cost strategy swings in various divisions of the economy, since mid-1980's, under the officially decided financing cost, thus, these progressions have influenced the total dimension of reserve funds and interest in the nation.

In addition, nearly pursued by the officially decided financing cost was the execution of loan fee under monetary changes. The goal was to advance funds, decrease bungle in venture, and in addition instigate powerful intermediation among savers and borrowers.

Regardless of the previously mentioned certainties, the Nigerian government is as yet attempting to develop the economy to the stature where it could be named as a created economy. This has offered ascend to researchable inquiries, for example, to what degree does loan cost influences funds and interest in an economy? Likewise, can loan cost be a moving component towards the accomplishment of monetary development in Nigeria? Along these lines, it is in light of this, that this examination is led to look at the impact of loan cost approach on the development of the Nigerian economy.

Moreover, there are three specific objectives of this study

i) Examining the effect of the rate of interest on gross domestic product in Nigeria;

ii) Investigating the effect of the rate of exchange on gross domestic product in Nigeria;

iii) To examine the effect of inflation on gross domestic product in Nigeria.

\section{Literature Review and Theoretical Underpinnings}

There are various theories that govern the activities of interest rate behaviour and economic growth. These theories include but not limited to the general equilibrium, liquidity preference and loanable funds.

The general equilibrium theory is related to synthesis of real sector and monetary sector as set forth by John Hicks. According to Nzotta (2004) the model was popularized by Alvin Hansen and later wound up known as the Hicks-Hansen synthesis. This theory hypothesized that loan costs (interest) rely upon the powers of both the real factors and monetary factors, and not on one of the two.

Here, general equilibrium involves flows from both sectors, while savings and investments will be equal in the real sector. Thus, at equilibrium; Savings $(\mathrm{S})=$ Investment (I) in the sector. On the other hand, Money Supply $(\mathrm{MS})=$ Money Demanded (MD) in the monetary sector. Thus, at equilibrium, the monetary sector and the real sector must be at equilibrium. At the end of the day, the equilibrium interest rate will be one at which these two conditions exist, and are fulfilled all the same time. This implies just a mix of the Keynesian and the Classical perspectives will prompt the estimation of the accurate rate of interest.

Again, the loanable fund theory (LFT) or loanable fund model is also referred to as the classical theory. It trusts that financing costs are dictated by the free market activity for loanable assets. In other words, market interest for arrangements or institutions through which savings from household/individuals are availed to borrowers is determined by the balance between suppliers and borrowers.

Jumbo (2005) opines that LFT supports the determination of market interest rate and expresses that the common rate of interest at a time shows to an equilibrium rate at which the individuals that demand for credit now, will level with the supply of credits from individuals who like to have interest. It includes the connecting of loan fees with investment funds, dishoarding and bank cash on the supply side.

The liquidity preference theory on the other hand was articulated by J. M Keynes. This hypothesis looks to clarify the dimension of interest concerning the association of two essential components namely, money supply and savers' desire to keep their funds in cash or near cash (their liquidity preference). Keynes explicitly rejected the postulations of the classical theory which posits that savings and investments are always equated by interest rates. He rather postulated: 
(a) That if no interest is payable on savings, then households are likely to hold their savings in cash.

(b) That the higher the level of interest, the more people would be prepared to forgo liquidity, and thus, more loanable funds would be available. Here, interest rates are the reward for not holding cash.

However, Keynes further maintained that money market discloses interest determinants and these are fundamentally, demand for money and money supply.

While the money supply is decided externally, those who demand for money rely upon the three thought processes in holding cash. These thought processes as indicated by Keynes include, holding cash for transactions, holding cash as precaution and holding cash due to speculations.

\subsection{The Structure of Interest Rate in Nigeria}

In view of the significant impact of interest rates on economic growth, the monetary authorities attach much importance to the structure and level of interest rates.

The Central Bank of Nigeria (CBN), for instance, is empowered to fix, vary and make public at all times its minimum rediscount rates. This rate refers to the minimum rate at which the Central Bank of Nigeria, in its role as a lender of last resort, makes or offers financial assistance (loans, bills discounted, etc.) to banks in the system. Deposit money banks' lending and borrowing rates and all money market rates are closely linked to the minimum rediscount rate. The structure of interest rates in Nigeria could be discussed under two phases:

- The era of administratively determined rate

- Interest rates under economic reforms

\subsubsection{The Era of Administratively Determined Rate}

The structure and level of interest rate before economic reforms in Nigeria were determined administratively by the Central Bank of Nigeria. The rates were fixed by the Central Bank of Nigeria on the basis of monetary policy thrusts, rather than on the operation of the market mechanism.

During the period of direct control of money supply, the interest rate policy was closely aligned with the credit policy. The credit policy over the years specified a sectorial classification of the credit portfolio of banks. This classification was made into two sectors; the preferred and non-preferred or other sectors.

With these classifications in focus, the monetary authorities fixed interest rates to direct financial resources at concessionary rates to the preferred sectors, which were considered important for faster economic growth. These concessionary rates were often below the minimum rediscount rates. On the other hand, the non-priority sectors attracted rates which were non-concessionary in nature.

For instance, between 1970 and 1974, the Central Bank of Nigeria changed the minimum rediscount rate several times, in an attempt to alter the interest rate structure, in consonance with the monetary policy posture and objectives of the government.

The minimum rediscount rate ranged between 4 per cent and 5 per cent during the period. The interest rate posture was essentially targeted at sustaining a low debt service on government debt, and also to enhance output, following the devastations of the civil war years. However, according to the 1978/1979 monetary policy guidelines, the maximum lending rate was 11 per cent.

The rates did not show significant changes until 1986. The Central Bank of Nigeria raised the maximum lending rates from 13 per cent to 15 per cent in 1986. Even though deposit rates were left unchanged, the policy guidelines gave the banks freedom to negotiate on an individual basis, higher rates with their customers. In 1987, the deposit rate was increased to 14 per cent. The maximum lending rate exceeded 18 per cent, while the minimum rediscount rate was increased from 10 per cent to 12.75 per cent. However, this interest rate posture changed with time. The concessionary rate structure was abolished with the deregulation of interest rates following the adoption of SAP in 1986.

\subsubsection{Interest Rates under Economic Reforms}

The deregulation of interest rates in Nigeria was essentially part of the general framework for the deregulation of the economy, enhancement of the achievement of the market mechanism in resource allocation, and in achieving rationality in resource use. The reforms implied the elimination or reduction of the excessive controls, which inhibited the growth and development of the economy.

They are anchored on the need to promote savings, reduce distortions in investment, and induce effective intermediation between savers and investors. The deregulation of interest rate is thus a central pillar in the economic reforms in the country. The deregulation tried to address the fundamental distortions which manifested during the era of administered rates. Interest rate deregulation commenced in 1987, with the adoption of the Structural Adjustment Progamme (SAP), when the Central Bank of Nigeria abolished all controls on interest rates, thus allowing the forces of demand and supply to determine the market rates. Here, the minimum rediscount rate influence the movement of the money market rates, and in line with general economic conditions (Uchendu, 1993).

As a result of the deregulation of the interest rates, the minimum rediscount rate was adjusted from 10 per cent in 1986 to 12.75 in 1988. Interest rates on treasury bills increased from 10 per cent to 12.75 in the same period. Maximum lending rate was on the average of about 19.5 per cent, while deposit rate was in the range of 15 per cent to 16.75 per cent.

Thus, the minimum rediscount rate of 12.75 per cent by the end of 1987 affected all other rates. The objective was the attempt to stimulate growth and investment in the economy. In 1989, the minimum rediscount rate was raised to 18.5 per cent, as the essence was to moderate monetary expansion, and thus, reduces inflationary pressures in the economy. Also in 1989, the apex financial institution in Nigeria (CBN) introduced the auctionbased system for the issue of treasury bills and certificates as part of the flexible interest rate policy.

One important development in the interest rate regime in Nigeria was the introduction of the Nigeria InterBank Offered Rate (NIBOR) in 1997. The Nigeria Inter-Bank Offered Rate is patterned along the lines of the London Inter-Bank Offered Rate (LIBOR). 
This has assisted in stabilizing the interest rate structure generally in the money market in Nigeria. The high interest rate up to 2003 was a major disincentive to invest. The focus of the 2002/2003 policy was to make the minimum rediscount rate and the interest rate policy to be dynamic and market driven. The monetary authorities thus, sought to reduce lending rate to 22.5 per cent. This was in attempt to enhance production, encourage growth of the real sector and the economy in general. However, the monetary authorities did peg the minimum rediscount rate at 15 per cent in 2004, reduce it to 8.75 in 2007, and further reduce it to an average of 7.44 in 2009.

\subsection{Empirical Review}

Review has shown that very few studies has examined on interest rate policy and economic growth. Significant of such studies are those of Utile et al. (2018) who examined the effect of interest rate on economic growth in Nigeria. Multiple regression technique was used for the analysis of data. It was found that inflation and exchange rate have negative and insignificant effect on Gross Domestic Product, while the deposit interest rate exerted a positive and significant impact on GDP, hence it was concluded that interest rate does not impact Gross Domestic Product.

Also, Osadume (2018) examined the effect of interest rate mechanism on economic development in Nigeria (1986-2016). The research work selected Nigeria as its sample, and adopted the Ordinary Least Square, Cointegration, Granger-causality and ECM to analyse the functional relationship or dependent variable and the dependent variables. The findings showed that discount rates, represented by interest and monetary policy rates, had significant effect in the short-run, and showed positive and significant effect in the long-run on economic development.

Moreover, Nkemakolam (2017) investigated the interest rate reforms and the impact on the Nigerian economic expansion, with annual time series data between 1986 and 2013. Using the Ordinary Least Square regression technique, a negative impact was established between interest rate reforms and the growth of the Nigerian economy, while Udoka and Anyingang (2012) examined the effect of interest rate fluctuations on the growth of the Nigerian economy using a time series data from 1970-2010. They established in their study using OLS a negative relationship between economic growth and interest rate, meaning that increase in interest rate will decrease Gross Domestic Product of the country, thus, retarding growth of the real sector.

\section{Model Specification}

Data proxied for the variables were obtained from the Central Bank of Nigeria (CBN) and the study adopted the bound testing approach to analyze the relationship among variables (Pesaran et al., 2001).

We analysed using autoregressive distributed lag model as opposed to conitegration test of Johansen and Juselius (1990) for three reasons. First, ARDL applies a reduced equation form and single equation and secondly, it gives room for variables not cointegrating at the same order. The implication is that some equations can cointegrate at levels while some at difference. The third reason is that ARDL is robust for utilization of various optimal lags for the variables. follows:

The estimated formula for the relationship existing between economic growth and interest in Nigeria is as LGDP = f(LINTR, LEXCR, LINF)

The Ordinary Least Square model showing relationship among the variables for the study can be captured as

Where;

$$
L G D P=\beta_{0}+\beta_{1} L_{I N T R}+\beta_{2} E X C H R_{t}+\beta_{3} I N T R_{t}+\varepsilon_{t}
$$

LGDP $=\log$ of Gross Domestic Product data, LINTR $=\log$ of Interest rate data. LEXCR $=\log$ of exchange rate time series data and LINF $=\log$ of Inflation, $\beta_{0}=$ constant term, and $\beta_{1}-\beta_{2}=$ parameters to be estimated, while $\varepsilon=$ stochastic error term

Hence our ARDL model is estimated for the changes in variables and transformed into

$$
\Delta L G D P=\propto_{0}+\sum_{j=1}^{k} \beta_{j} \Delta L I N T R_{t-1}+\sum_{j=1}^{k} \lambda_{j} \Delta E X C H R_{t-1}+\sum_{j=1}^{k} \lambda_{j} \Delta I N T R_{t-1}+\varepsilon_{t} \ldots \ldots \ldots \ldots
$$

\section{Empirical Results and Analysis}

\begin{tabular}{|c|c|c|c|c|}
\hline \multicolumn{5}{|c|}{$\begin{array}{l}\text { Correlation Coefficients, using the observations } 1-27 \\
5 \% \text { critical value (two-tailed) }=0.3809 \text { for } \mathrm{n}=27\end{array}$} \\
\hline 1_GDP(N)Billion & 1_INTR & 1_EXCHR & 1_INFR & \\
\hline \multirow[t]{4}{*}{1.000} & -0.6064 & 0.9257 & -0.4369 & 1_GDP(N)Billion \\
\hline & 1.000 & -0.4474 & 0.3409 & 1_INTR \\
\hline & & 1.000 & -0.4195 & 1_EXCHR \\
\hline & & & 1.000 & 1_INFR \\
\hline
\end{tabular}

Table-4.1. Correlation Analysis for Variables

Source: Researcher's compilation with GRETL

Table-4.2. Stationarity Test (ADF)

\begin{tabular}{l|l|l|l|l|l|l}
\hline \multicolumn{7}{l}{ Augmented Dickey-Fuller Test for stationarity of the variables } \\
\hline & & & LEVEL & PROB & DIFFERENCE & PROB \\
\hline $\mathbf{1 0 \%}$ & $5 \%$ & $1 \%$ & & & & \\
\hline $\mathbf{0 . 3 5 5}$ & 0.462 & 0.707 & 0.602534 & 0.027 & 0.105399 & $>.10$ \\
\hline $\mathbf{0 . 3 5 5}$ & 0.462 & 0.707 & 0.983954 & $<.01$ & 0.556757 & 0.034 \\
\hline $\mathbf{0 . 3 5 5}$ & 0.462 & 0.707 & 0.887202 & $<.01$ & 0.181634 & $>.10$ \\
\hline $\mathbf{0 . 3 5 5}$ & 0.462 & 0.707 & 0.323195 & $>.10$ & 0.084481 & $>.10$ \\
\hline
\end{tabular}


Table-4.3. KPSS Test for stationarity of the variables

\begin{tabular}{l|l|l|l|l}
\hline \multicolumn{2}{l}{ Critical values } & $\mathbf{0 . 1 4 9}$ & & \\
\hline LGDP & 0.211214 & $<.01$ & 0.055596 & $>.10$ \\
\hline LINTR & 0.070221 & $>.10$ & 0.07039 & $>.10$ \\
\hline LEXCHR & 0.198618 & 0.017 & 0.060128 & $>.10$ \\
\hline LINFL & 0.066437 & $>.10$ & 0.081974 & $>.10$ \\
\hline
\end{tabular}

Source: Researcher's compilation with GRETL

To test if the variance, co-variance and mean were constant over time in the time series trend, both ADF and KPSS test were conducted at levels and difference for each variables.

KPSS test is one sided LM Statistics, hence if the critical value is lower than the LM Statistic, we reject the null hypothesis, the series is non-stationary. From the tests above, it can be concluded that some factors in the equation were stationary at levels, while others became stationary at first difference.

\section{Test For Multicollinearity}

VIF Minimum possible value $=1.0$

Values $>10.0$ may indicate a collinearity problem
LINTR 1.296
LEXCHR 1.390
LINFL 1.258

$\operatorname{VIF}(j)=1 /\left(1-R(j)^{\wedge} \mathcal{Q}\right)$, where $R(j)$ is the multiple correlation coefficient between variable $\mathrm{j}$ and the other independent variables

Since all the values $(1.296,1.390,1.258)$ are less than 10.0 we can comfortably conclude no multicollinearity problem. Belsley-Kuh-Welsch collinearity diagnostics:

\begin{tabular}{ccccccc} 
& \multicolumn{7}{c}{--- variance proportions --} \\
lambda & cond & const & \multicolumn{2}{c}{ LINTR } & LEXCHR & LINFL \\
3.897 & 1.000 & 0.000 & 0.000 & 0.002 & 0.003 & \\
0.083 & 6.833 & 0.000 & 0.000 & 0.237 & 0.293 & \\
0.019 & 14.385 & 0.020 & 0.037 & 0.503 & 0.703 & \\
0.001 & 60.102 & 0.980 & 0.962 & 0.257 & 0.001 &
\end{tabular}

lambda $=$ eigenvalues of $\mathrm{X}^{\prime} \mathrm{X}$, largest to smallest

cond $=$ condition index

note: variance proportions columns sum to 1.0

Result: From the above test, since all the values $(1.296,1.390,1.258)$ are less than 10.0 we can comfortably conclude no multicollinearity problem.

Table-4.4. Regression result for model

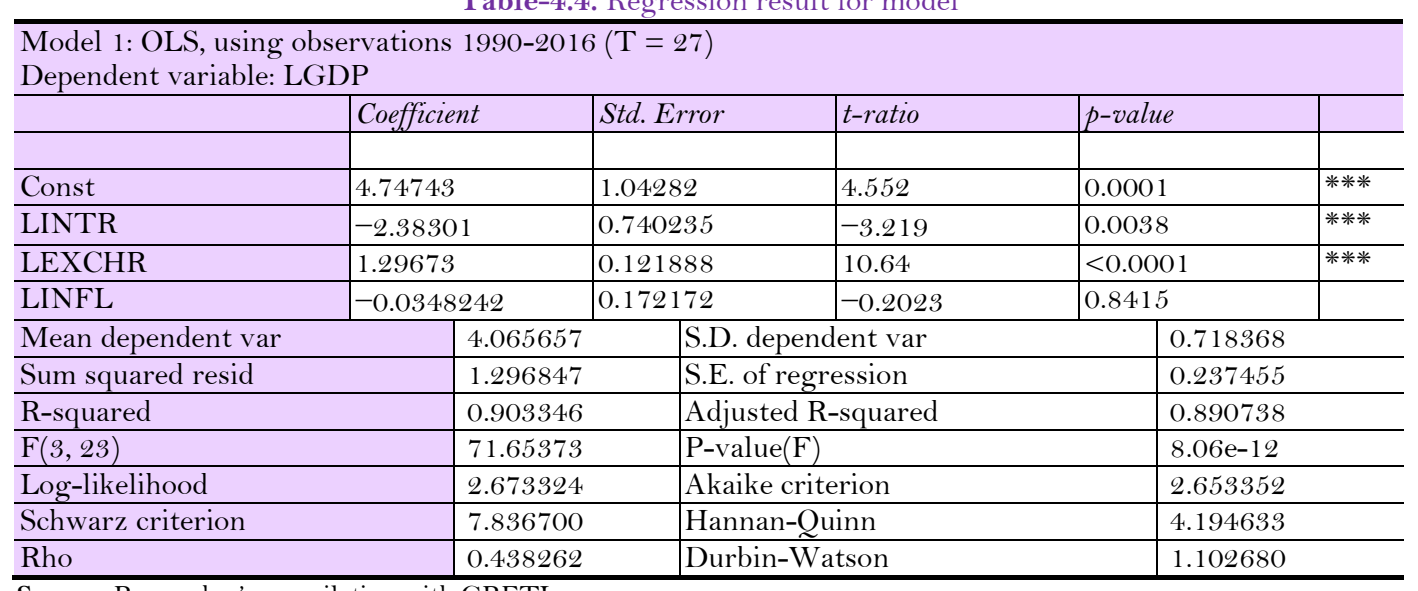

Source: Researcher's compilation with GRETL

Specification Test: Durbin Watson Test.

From Table 4.4, We can see Durbin-Watson statistic $=1.10268$. Hence we conducted a DW test to check for the p-value. The p-value $=0.00190583$, hence we conclude that there is a positive auto correlation (AR1). We can re-confirm this by using Breusch-Godfrey test below.

\section{Breusch-Godfrey Test for First-Order Autocorrelation}

OLS, using observations 1990-2016 $(\mathrm{T}=27)$

Dependent variable: uhat

coefficient std. error t-ratio p-value

$\begin{array}{lcccc}\text { const } & -2.50092 & 2.35897 & -1.060 & 0.3006 \\ \text { l_INTR } & 0.741954 & 0.722674 & 1.027 & 0.3157 \\ \text { l_EXCR } & 0.0550125 & 0.111242 & 0.4945 & 0.6258 \\ \text { l_INF } & 0.0373095 & 0.154899 & 0.2409 & 0.8119 \\ \text { uhat_1 } & 0.535302 & 0.207350 & 2.582 & 0.0170\end{array}$ **


Unadjusted R-squared $=0.232509$, Test statistic: $\mathrm{LMF}=6.664846$, with p-value $=\mathrm{P}(\mathrm{F}(1,22)>6.66485)=$ 0.017

Alternative statistic: $\mathrm{TR}^{\wedge} 2=6.277754$, with p-value $=\mathrm{P}($ Chi-square $(1)>6.27775)=0.0122$

Ljung-Box $Q^{\prime}=5.68162$, with p-value $=\mathrm{P}($ Chi-square $(1)>5.68162)=0.0171$

From the Breusch-Godfrey test, the alternative statistic is 6.277754 and the p-value of 0.0122 which is very small. So we reject the alternative hypothesis and accept that there is a positive AR1.

It means that the model suffers from auto correlation and the standard errors on ols regression are wrong.

In order to correct the autocorrelation problem seen in the model, we adopted Cochrane-Orcutt iterative process resulting in a better Durbin Watson value. Result for the ADL model is shown below.

ADL Result for the variables

\begin{tabular}{|c|c|c|c|c|c|}
\hline \multicolumn{6}{|c|}{$\begin{array}{l}\text { Model 2: Cochrane-Orcutt, using observations 1991-2016 }(\mathrm{T}=26) \\
\text { Dependent variable: LGDP } \\
\text { rho }=0.956309\end{array}$} \\
\hline & Coefficient & Std. Error & t-ratio & $p$-value & \\
\hline$\overline{\text { Const }}$ & 6.17528 & 0.251418 & 24.56 & $<0.0001$ & ***** \\
\hline LINTR & 0.118213 & 0.0915043 & 1.292 & 0.2098 & \\
\hline LEXCHR & -0.0917353 & 0.0617636 & -1.485 & 0.1517 & \\
\hline$\overline{\mathrm{LINFL}}$ & 0.0292971 & 0.0331011 & 0.8851 & 0.3857 & \\
\hline
\end{tabular}

Statistics based on the rho-differenced data:

\begin{tabular}{l|l|l|l}
\hline Mean dependent var & 4.118232 & S.D. dependent var & 0.677551 \\
\hline Sum squared resid & 0.029351 & S.E. of regression & 0.036526 \\
\hline R-squared & 0.997443 & Adjusted R-squared & 0.997094 \\
\hline $\mathrm{F}(3,22)$ & 1.263232 & P-value $(\mathrm{F})$ & 0.311359 \\
\hline Rho & 0.067299 & Durbin-Watson & 1.909917 \\
\hline
\end{tabular}

From the above result, it could be deduced that if all the independent variables are held constant, the Nigeria Economy will stand at 6.71752 respectively using autoregressive lag technique. Again, the result showed that all macroeconomic indicators have positive relationship with the Nigeria economy as the parameters entered the model with positive sign except exchange rate (LEXCHR).

Implying that a unit increase in interest rate and inflation results in 0.118213 and 0.0292971 increase in economic growth, while a unit increase in exchange rate to lead to 0.0917353 reduction in the growth of the economy.

The goodness of fit of the model is indicated by the adjusted $\mathrm{R}^{2}$ value of 0.997094 or 99.7 per cent, indicating that the model fits the data well. The total variation in the observed behavior of the Nigeria economy is jointly predicted by the variation in interest rate, exchange rate and inflation up to 96.6 per cent, the remaining 1.3 per cent is accounted for by the stochastic error term.

Note that after the iteration here, the Durbin-Watson value of 1.909917 has improved compared to the Ordinary Least Square of 1.102680

In order to test the hypotheses, the following decision rule is specified.

Decision rule

The decision rule is to reject the hypothesis if the $t$-calculated is $>t$-table, and accept the null hypothesis if the $\mathrm{t}$-calculated is $<\mathrm{t}$ - table.

Result of hypothesis one

T-calculated for INTR $=1.292$

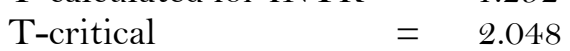

P-value $\quad=0.2098$ (higher than 0.05)

Result of hypothesis Two

T-calculated for EXCR $=1.485$

T-critical $\quad=2.048$

$\mathrm{P}$-value $\quad=0.1517$ (higher than 0.05 )

Result of Hypothesis Three

$\mathrm{T}$-calculated for INF $=0.8851$

T-critical $=2.048$

P-value $\quad 0.3857$ (higher than 0.05) 


\section{Test of Hypotheses}

Based on our decision rule and using the p-value of the factors, we can conclude that the findings of the influence of interest rate, exchange rate and inflation rate is not significant at $5 \%$ level of significance. Hence we reject the alternative hypothesis. Consequently, we can conclude that Interest rate does not impact the growth of the GDP.

\section{Discussion of Findings}

The study empirically examined the effect of interest rate policy on the growth of the Nigerian economy. Based on the analysis of the results, the study revealed that a relationship exists between interest rate and economic growth though insignificant.

This by implication means that increase in the interest rate paid on deposit, will simultaneously encourage the banking populace to save, thus, making more funds available for lending to investors, which will certainly lead to a corresponding increase in economic growth. This finding is supported by the findings of Osadume (2018) which establishes that interest rate has a significant effect in both the short-run and long-run period of economic development in Nigeria.

Again, Acha and Acha (2011) supported this notion when they asserted that interest rate cannot predict savings and investment in Nigeria.

This by implication means that increase in the interest rate paid on deposit, will simultaneously encourage the banking populace to save, thus, making more funds available for lending to investors, which will certainly lead to a corresponding increase in economic growth. This finding is supported by the findings of Osadume (2018) which establishes that interest rate has a significant effect in both the short-run and long-run period of economic development in Nigeria.

The study also revealed that exchange rate has an effect though not significant on economic growth. This by implication indicates that a favourable increase in exchange rate will lead to reduced growth in the Nigeria economy.

Another major finding of the study revealed that there is a relationship though not significant between inflation and economic growth in Nigeria. This finding is in line with the findings obtained by Adeniran et al. (2014) which established that there is a direct relationship between inflation and economic growth in Nigeria.

Conclusively, the interest rate is a pivot that accelerates other sectors to achieve economic growth in Nigeria. This is evident, as the study had examined the effect of interest rate policy on the growth of the Nigerian economy, and the result showed that interest rate is a determinant of economic growth, as measured by gross domestic product.

This implies that increase in interest rate will encourage savers to save, thus, making more funds available in the banking system, and hereby inducing economic growth.

\section{Recommendations}

In view of the above summary of findings, the following are recommended.

i) The government should channel their policy thrust towards increase in aggregate output, through lowering of lending rate and increasing deposit rate, as this enhances economic growth.

ii) A strong monetary policy for Nigeria should not be based on interest rate regulation, except our financial sector is improved, and the awareness of the activities of the financial institutions taken to ordinary Nigerians.

iii) The Central Bank of Nigeria should adopt interest rate policy that will always boost the savings culture of the real sector. This can be achieved by increasing the interest rate paid to deposit made by individuals, local and foreign investors.

iv) Monetary policy rates as well as interest rates should be environment and business-friendly, and predictable in line with prevailing economic dictates and conditions.

v) Interest rate should be liberalized in Nigeria.

\section{References}

Acha, I.A. and C.K. Acha, 2011. Interest Rates in Nigeria: An Analytical perspective, Research Journal of Finance and Accounting, 2(3): 7181.

Adeniran, J., S. Yusuf and O.A. Adeyemi, 2014. The impact of exchange rate fluctuation on the nigerian economic growth: An empirical investigation. The impact of exchange rate fluctuation on the Nigerian economic growth: An empirical investigation. International Journal of Academic Research in Business and Social Sciences, 4(8): 224-233. Available at: https://doi.org/10.6007/ijarbss/v4i8/1091.

Colander, D.C., 2001. Economics. Boston: McGraw Hill Irwin.

Emori, E.G., E.N. Obim, A.O. Eba and C.C. Emefiele, 2017. Effect of bank lending rate on the performance of Nigerian economy. European Journal of Business and Management, 9(21): 92-95.

Johansen, S. and K. Juselius, 1990. Maximum likelihood estimation and inference on cointegration-with applications to the demand for money. Oxford Bulletin of Economics and Statistics, 52(2): 169-210. Available at: https://doi.org/10.1111/j.14680084.1990.mp52002003.x.

Jumbo, C.O., 2005. Elements of banking. Owerri: Barloz Publishers Inc.

Mankiw, N.G. and L.H. Summers, 1984. Do long-term interest rates overreact to short-term interest rates? Brookings Papers on Economic Activity, 15(1): 223-247.

Nkemakolam, A.C., 2017. Effect of interest rate reforms on economic growth of Nigeria. International Journal of Social Sciences and Humanities Reviews, 7(1): 229-235.

Nzotta, S.M., 2004. Money, banking and finance (theory and practice). Owerri: Hudson-Jude Nigeria Publishers.

Ojima, D. and E. Fabian, 2015. Impact of interest rate on investment in Nigeria, Developing Country Studies, 5(3): $103-109$.

Olusoji, M., 2003. Determinants of private savings in Nigeria: An error correction approach. NDIC Quarterly, 13(3): 29-38.

Orok, A.B., I.O. Okoi and A. Essien, 2018. Inflation and deposit mobilization in deposit money banks - the Nigerian perspective" International Journal of Public Administration and Management Research, 4(4): 109-121.

Osadume, R., 2018. Effect of interest rate mechanism on the economic development of Nigeria. International Journal of Economics and Business Management, 4(4): 91-115. 
Pesaran, M.H., Y. Shin and R.J. Smith, 2001. Bounds testing approaches to the analysis of level relationships. Journal of Applied Econometrics, 16(3): 289-326. Available at: https://doi.org/10.1002/jae.616.

Powell, J.H., 2015. Financial institutions, financial markets, and financial stability, speech delivered at the stern school of business. New York University: New York.

Uchendu, O., 1993. Interest rate policy, savings and investment in Nigeria. Central Bank of Nigeria Economic and Financial Review, 31 (1): 34-52.

Udoka, C.O. and R.A. Anyingang, 2012. The effect of interest rate fluctuation on the economic growth of Nigeria. International Journal of Business and Social Science, 3(20): 295-302.

Utile, B.J., A.O. Okwori and M.D. Ikpambese, 2018. Effect of interest rate on economic growth in Nigeria. International Journal of Advanced Academic Research, 4(1): 66-76.

Citation | Edim Ndifon Obim; John Ime John; Akaninyene Billy Orok (2018). Interest Rate Policy and the Growth of the Nigerian Economy (1990-2016). Journal of Banking and Financial Dynamics, 2(1): $16-23$.

\section{History:}

Received: 16 October 2018

Revised: 20 November 2018

Accepted: 24 December 2018

Published: 18 January 2019

Licensed: This work is licensed under a Creative Commons

Attribution 3.0 License (c)) E

Publisher: Eastern Centre of Science and Education
Acknowledgement: All authors contributed to the conception and design of the study.

Funding: This study received no specific financial support.

Competing Interests: The authors declare that they have no conflict of interests.

Transparency: The authors confirm that the manuscript is an honest, accurate, and transparent account of the study was reported; that no vital accurate, and transparent account of the study was reported; that no vital
features of the study have been omitted; and that any discrepancies from the study as planned have been explained.

Ethical: This study follows all ethical practices during writing.

Eastern Centre of Science and Education is not responsible or answerable for any loss, damage or liability, etc. caused in relation to/arising out of the use of the content. Any queries should be directed to the corresponding author of the article. 